\title{
Esophagus and Esophagogastric Junction Cancer Pathologic Regional Lymph Nodes TNM Finding v7
}

National Cancer Institute

\section{Source}

National Cancer Institute. Esophagus and Esophagogastric Junction Cancer Pathologic Regional Lymph Nodes TNM Finding v7. NCI Thesaurus. Code C89737.

A pathologic finding about one or more characteristics of esophagus and esophagogastric junction cancer, following the rules of the TNM AJCC V7 classification system as they pertain to staging of regional lymph nodes. 